\title{
М. М. Вінічук
}

Шведський університет сільськогосподарських наук, Уппсала, Швеція Житомирський державний технологічний університет, Житомир, Украӥна

\section{ТОРІЙ ТА УРАН У ФРАКЦІЯХ ГРУНТУ ТА ОКРЕМИХ ВИДАХ МАКРОМІЦЕТІВ БОРЕАЛЬНИХ ЛІСОВИХ ЕКОСИСТЕМ}

Досліджено вміст торію (Th) та урану (U) у фракціях грунту едафосфера, ризосфера, ризоплана, міцелії грибів та їх плодових тілах. Концентрація торію у фракції едафосфера, ризосфера та міцелії грибів суттєво не відрізняється (0,74-1,45 мг/кг сухої ваги), тоді як у фракції ризоплана вміст торію учетверо нижчий, ніж у загальній масі грунту - едафосфері. Концентрація урану у фракції едафосфера, ризосфера, ризоплана та міцелії грибів суттєво не відрізняється (3,11-9,36 мг/кг сухої ваги). Вміст обох природних ізотопів у плодових тілах грибів у 270 разів нижчий, ніж у загальній масі грунту: коефіцієнти біологічного поглинання урану та торію плодовими тілами грибів у середньому становлять 0,035 та 0,006 відповідно. Вміст торію та урану як у міцелії грибів, так і у плодових тілах зростає при підвищенні їх вмісту у грунті. У міцелії грибів верхнього (0-5 см) шару лісового грунту може бути зосереджено 2,0-5,0 та 1,4-2,7 \% торію та урану від їх загального вмісту відповідно.

\section{М. М. Виничук}

Шведский университет сельскохозяйственных наук, Уппсала, Швеиия Житомирский государственный технологический университет, Житомир, Украина

\section{ТОРИЙ И УРАН ВО ФРАКЦИЯХ ПОЧВЫ И ОТДЕЛЬНЫХ ВИДАХ МАКРОМИЦЕТОВ БОРЕАЛЬНЫХ ЛЕСНЫХ ЭКОСИСТЕМ}

Исследовано содержание тория (Th) и урана (U) во фракциях почвы эдафосфера, ризосфера, ризоплана, мицелии грибов и их плодовых телах. Концентрация тория во фракциях эдафосфера, ризосфера и мицелии грибов существенно не отличается (0,74-1,45 мг/кг сухого вещества), тогда как во фракции ризоплана концентрация тория в 4 раза ниже, чем в общей массе почвы - эдафосфере. Концентрация урана во фракции эдафосфера, ризосфера, ризоплана и мицелии грибов существенно не отличается (3,11-9,36 мг/кг сухого вещества). Содержание обоих природных изотопов в плодовых телах грибов в 270 раз ниже, чем в общей массе почвы: коэффициенты биологического поглощения урана и тория плодовыми телами грибов в среднем составляют 0,035 и 0,006 соответственно. Содержание тория и урана как в мицелии грибов, так и плодовых телах возрастает при повышении их концентрации в почве. В мицелии грибов верхнего (0-5 см) слоя лесной почвы может быть сосредоточено 2,0-5,0 и 1,4-2,7 \% тория и урана от их общего содержания соответственно.

\section{M. Vinichuk}

Swedish University of Agricultural Sciences, Uppsala, Sweden Zhytomyr State Technological University, Zhytomyr, Ukraine

\section{THORIUM AND URANIUM IN SOIL FRACTIONS AND CERTAIN MACROMYCETE SPECIES IN BOREAL FOREST ECOSYSTEMS}

The content of thorium (Th) and uranium $(U)$ in fractions of soil edaphosphere, rhizosphere, rhizoplane, fungal mycelium and fruit bodies were investigated. The concentrations of thorium in edaphosphere 
and rhizosphere fractions and mycelia of fungi are not different significantly and vary in the range of 0.74 $1.45 \mathrm{mg} \mathrm{kg}^{-1}$ dry matter. The concentration of thorium in the rhizoplane fraction is 4 times lower than in the bulk soil - edaphosphere. The concentrations of uranium in edaphosphere, rhizosphere and rhizoplane fractions and fungi mycelium are not significantly different and vary between 3.11 and $9.36 \mathrm{mg} \mathrm{kg}^{-1} \mathrm{dry}$ matter. The content of the studied natural isotopes in fruit bodies of fungi is $\mathbf{2 7 0}$ times lower than in the bulk soil: biological absorption coefficients of uranium and thorium in fruit bodies are on average 0.035 and 0.006 , respectively. The contents of thorium and uranium in fungal mycelium and fruit bodies increase with increasing their concentrations in the soil. It is shown that in the fungi mycelium of the upper $(0-5 \mathrm{~cm})$ layer of forest soil can be allocated $2.0-5.0$ and $1.4-2.7 \%$ of the total thorium and uranium soil content, respectively.

\section{Вступ}

Ектомікоризні гриби - характерні компоненти грунтів лісових екосистем бореальних хвойних лісів та лісів помірних широт. Міцелій цих грибів відіграє вирішальну роль у живленні вищих рослини завдяки формуванню симбіотичних асоціацій. Мікоризні гриби збільшують поглинальну поверхню коренів рослин і сприяють мобілізації поживних речовин з органічних решток унаслідок дії гідролітичних позаклітинних ферментів [7].

Міцелій мікоризних грибів також забезпечує поглинання з грунту широкого спектра елементів мінерального живлення [11], у тому числі макроелементів, таких як фосфор [4], та цілого ряду мікроелементів [7]. При цьому поглинаються як есенціальні (життєво необхідні), так і мікроелементи, які, будучи антропогенними забруднювачами, можуть при підвищених концентраціях бути токсичними для людини [15]. Науковий інтеpec до вивчення грибів виявляється у тому числі і через здатність останніх до вибіркового поглинання елементів, небезпечних для людини. Добре відома здатність грибів накопичувати радіонукліди [16]), у тому числі і природні радіоізотопи [2]. Плодові тіла багатьох видів макроміцетів можуть містити важкі метали, у тому числі і кадмій, який накопичується грибами найінтенсивніше [9]. Деякими видами грибів (насамперед їх плодовими тілами) найбільшою мірою поглинаються уран та торій, хоча різні види екотомікоризних грибів відрізняються здатністю поглинати та накопичувати елементи [5; 14]. Плодові тіла ектомікоризних грибів становлять лише близько 1 \% (0,5 \%) біомаси усього міцелію у грунті [13]. Переважна частина біомаси тіла гриба (міцелій) міститься у верхніх, багатих на органічну речовину шарах лісового грунту. Здатність міцелію грибів накопичувати елементи, у тому числі радіоізотопи, досліджена недостатньо [16]. Відомі лише декілька праць, у яких зроблено спроби проаналізувати вміст мікроелементів у міцелії грибів, що зростають у природних умовах [3; 13]. Остаточно не встановлено, яким чином природні ізотопи, поглинені міцелієм ектомікоризних грибів, надходять із грунту по трофічних ланцюгах до плодових тіл. Важливі з погляду розуміння цих процесів функції таких фракцій грунту як ризосфера та ризоплана, в яких формуються найближчі трофічні взаємозв'язки. Співвідношення концентрації елементів у грибах до їх концентрації у грунті та окремих їх фракціях дає уявлення про акумуляційну здатність останніх.

Тому мета даної роботи - оцінити динаміку зміни концентрації торію та урану у трофічному ланцюзі: едафосфера, ризосфера, ризоплана, міцелій ектомікоризних грибів та плодові тіла. Крім того, у роботі наведено величини коефіцієнтів біологічного поглинання цих природних радіоізотопів ектомікоризними грибами та показано залежності між їх концентрацією у грунті та вмістом у грибах.

\section{Матеріали і методи досліджень}

Дослідження проводили у лісових екосистемах східного узбережжя Центральної Швеції (60 22" пн. ш., $18^{\circ} 13^{\prime \prime}$ сх. д.). Грунти глинисто-піщані, у трав'янистому покриві переважають чорниця (Vaccinium myrtillus L.), орляк звичайний (Pteridium aquilinum 
(L.) Kuhn), підбіл звичайний (Tussilago farfara L), хвощ лісовий (Equisetum silvaticum L.). У насадженнях переважають ялина європейська (Picea abies (L.) H. Karst.) та сосна звичайна (Pinus sylvestris L.) віком близько 100 років. Детальніший опис досліджуваних екосистем наведено у Lundin et al. [12]. Зразки грунту та плодові тіла грибів відбирали протягом вересня - листопада 2003 року з десяти ділянок (близько 10 м $^{2}$ кожна), розміщених на відстані 20-50 м одна від іншої на площі близько 2,0 га. На кожній ділянці відбирали чотири зразки грунту за допомогою циліндричного бура 5,7 см у діаметрі до глибини 10 см навколо та безпосередньо у місцях зростання плодових тіл грибів (з площі $\approx 0,5 \mathrm{~m}^{2}$ ) у межах кожної ділянки. У тих же місцях відібрали плодові тіла 12 видів грибів, визначали їх видову належність, після чого висушили їх при температурі $+35^{\circ} \mathrm{C}$ до постійної ваги для визначення концентрації $U$ та $T h$. Аліквотні частини зразків грунту (30-50 г), відібраних із глибини 0-5 та 5-10 см, були використані для хімічного аналізу та вилучення міцелію. Грибні структури вилучали 3 грунту під мікроскопом середнього (х 60) збільшення з додаванням невеликої кількості дистильованої води. Приготовлений у такий спосіб зразок містив різні форми міцелію: окремі ниткоподібні відгалуження гриба, міцеліальні тяжі, ризоморфи, окремі склероції та невелику кількість інфікованих мікоризних кінчиків коренів. Метод вилучення міцелію наведено у Vinichuk \& Johanson [16]. Із грунтових зразків вилучали фракції грунту відповідно до методики, наведеної у Gorban \& Clegg [6]. Фракцію едафосфера одержали шляхом просіювання лісового грунту, 3 якого попередньо вилучили великі корені дерев і каміння через сито з розміром отворів 2 мм. Фракцію ризосфера одержали шляхом відділення вручну часток грунту, асоційованого з дрібними та середнього розміру коренями, що залишились на ситі після просіювання. Фракція, що залишилась після цього (дрібні корені рослин і частки грунту безпосередньо на них), одержала назву ризоплана. Всього проаналізовано 9 зразків фракції едафосфера та міцелію, 12 зразків плодових тіл грибів, 6 зразків фракції ризосфера та 6 зразків ризоплана.

Вміст органічної речовини грунту визначали шляхом спалювання грунту при температурі $550{ }^{\circ} \mathrm{C}, p H$ грунту визначали у $1: 5$ «грунт : вода» суспензії (5 г грунту). Концентрацію елементів у зразках визначали масспектрометричним методом (ICP-MS) у лабораторії ALS Scandinavia AB, Luleå за методикою, наведеною у Rodushkin et al., [8]. Коефіцієнт біологічного поглинання (Кбп) визначали як відношення концентрації елемента (мг/кг сухої речовини) у грибах чи фракціях грунту до концентрації елемента (мг/кг сухої речовини) в едафосфері для шару грунту 0-10 см. Статистичну обробку даних проводили 3 використанням дисперсійного аналізу (ANOVA) і коефіцієнтів кореляції за Пірсоном. Програмне забезпечення Minitab (C 2010 Minitab Inc).

\section{Результати та їх обговорення}

Кислотність грунту дослідних ділянок була доволі високою: у шарі грунту 05 см показник $p H$ становив 5,2 (діапазон 3,8-6,9), а в шарі 5-10 см - 5,1 (діапазон 3,67,1). Для всього досліджуваного грунтового профілю (0-10 см), найвищі показники $p H$ $(6,5-6,9)$ спостерігались на ділянках 1,2 і 5. У зразках грунту інших ділянок значення $p H$ варіювали у межах від 3,7 до 5,1.

Вміст органічних речовин у грунтах дослідних ділянок також високий: у шарі 05 см він становив 66,2 \% (діапазон 36,4-97,7), а в шарі 5-10 см - 52,9 \% (діапазон 21,296,6). Для всього (0-10 см) шару грунту високий вміст органічних речовин спостерігався на ділянках 5 (84,0 \%), 8 (85,9 \%) та 9 (97,7 \%).

Вміст торію та урану у грибах залежить від кислотності грунту. Позитивний кореляційний зв'язок $(r=0,91 * * *$ та $r=0,50)$ існує між величиною $p H$ та вмістом ура- 
ну, а також між величиною $p H$ та вмістом торію $(r=0,33$ та $r=0,52)$ у міцелії грибів та їх плодових тілах, відповідно. Відомості щодо впливу величини кислотності грунту на надходження торію та урану в ектомікоризних грибах відсутні. Разом із тим відомо, що біомаса цвілевих грибів 3 роду Penicillium адсорбує найбільші кількості урану при величині $p H$ 3,0-7,5 [10]. Між вмістом органічних речовин у досліджуваних грунтах і концентрацією елементів у міцелії грибів залежність обернено пропорційна: $r=-0,66$ * та $r=-0,51$ для торію та урану відповідно. У плодових тілах грибів концентрація урану слабо залежить від вмісту органічних речовин $(r=0,42)$, тоді як між концентрацією торію та вмістом органіки грунту залежність взагалі відсутня $(r=-0,17)$. Імовірно, що крім кислотності грунту надходження урану та торію у гриби залежатиме і від ряду інших факторів, зокрема окисно-відновного потенціалу та концентрації елементів у грунті.

У загальній масі грунту вміст торію складає 0,13-2,94, а урану 0,07-36,7 мг/кг. Вміст торію у зоні ризосфери дещо вищий порівняно з умістом його у грунті, але різниця знаходиться у межах варіації. Концентрація торію у міцелії грибів була дещо нижчою вмісту його у грунті, тоді як вміст його у плодових тілах на два порядки нижчий, ніж у грунті. Оскільки фракція ризоплана по суті являє собою дрібні корені рослин із частками грунту безпосередньо на них, можна стверджувати, що кореневою системою рослин (дерев) досліджувані природні ізотопи поглинаються, але не накопичуються. Особливо це стосується торію, концентрація якого у фракції ризоплана виявилась статистично достовірно нижчою порівняно з умістом його у загальній масі грунту - едафосфері при рівні значимості $p<0,026$. Імовірно, що у рослинах вміст цих природних радіоактивних елементів буде ще нижчим, оскільки метали після поглинання їх коренями акумулюються останніми. Концентрація урану у грунті ушестеро вища концентрації торію і також варіювала у досліджуваних фракціях грунту та міцелії, але несуттєво (табл. 1).

Вміст урану у плодових тілах виявився також на два порядки нижчим, ніж у едафосфері. Вміст торію та урану у плодових тілах грибів досить добре збігається з оцінками інших авторів. Вміст урану та торію у плодових тілах грибів, що зростали у незабруднених лісових екосистемах Чехії [14], був нижчий 30 та 125 мкг/кг сухої ваги відповідно.

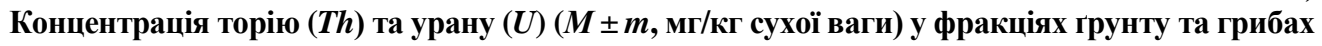

\begin{tabular}{|l|c|c|c|c|c|}
\hline Елементи & Едафосфера $(n=9)$ & Ризосфера $(n=6)$ & Ризоплана $(n=6)$ & Міцелій $(n=9)$ & Плодові тіла $(n=13)$ \\
\hline$T h^{*}$ & $1,10 \pm 0,30^{\mathrm{a}}$ & $1,45 \pm 0,50^{\mathrm{a}}$ & $0,28 \pm 0,09^{6}$ & $0,74 \pm 0,23^{\mathrm{a}}$ & $0,0041 \pm 0,0009$ \\
\hline$U$ & $6,85 \pm 4,02^{\mathrm{a}}$ & $9,36 \pm 3,99^{\mathrm{a}}$ & $5,79 \pm 2,81^{\mathrm{a}}$ & $3,11 \pm 1,24^{\mathrm{a}}$ & $0,026 \pm 0,016$ \\
\hline
\end{tabular}

Примітка: * - середні значення ряду з різними індексами (a, б) є статистично відмінними $(p<0,026)$.

Як видно з коефіцієнтів біологічного поглинання урану та торію у фракціях грунту та грибах до їх концентрації в едафосфері, концентрація торію у фракції ризоплана у 56 разів, а концентрація урану - удвічі нижча їх вмісту у загальній масі грунту - едафосфері. Коефіцієнти біологічного поглинання урану та торію плодовими тілами у середньому для досліджуваних видів грибів становлять 0,035 та 0,006 відповідно (табл. 2). Отже, вміст досліджуваних природних ( $U$ та $T h$ ) радіоізотопів у плодових тілах ектомікоризних грибів у 30 та 140 разів нижчий їх концентрації у грунті відповідно.

Уран і торій надходять у плодові тіла грибів, але накопичення їх не спостерігається. Аналогічних висновків дійшли і чеські дослідники, які проаналізували вміст цих природних ізотопів у плодових тілах грибів лісових екосистем, що не зазнали антропогенного забруднення [14]. Коефіцієнти біологічного поглинання урану та торію у 
плодових тілах досліджуваних видів грибів варіюють у широкому діапазоні, але значно менше 1 (табл. 3).

Табличя 2

Коефіціснти біологічного поглинання $(M \pm m)$ торію $(T h)$ та урану $(U)$ у фракціях грунту та грибах

\begin{tabular}{|l|c|c|c|c|}
\hline \multicolumn{1}{|c|}{ Елементи } & Ризосфера & Ризоплана & Міцелій & Плодові тіла \\
\hline$T h$ & $0,85 \pm 0,24$ & $0,18 \pm 0,04$ & $0,64 \pm 0,16$ & $0,006 \pm 0,002$ \\
\hline$U$ & $1,05 \pm 0,19$ & $0,52 \pm 0,18$ & $0,99 \pm 0,29$ & $0,035 \pm 0,021$ \\
\hline
\end{tabular}

Коефіцієнт біологічного Поглинанняторію (Th) та урану (U) для плодових тіл грибів

Таблиия 3

\begin{tabular}{|c|l|c|c|}
\hline Місця відбору зразків & \multicolumn{1}{|c|}{ Види грибів } & $T h$ & $U$ \\
\hline 1 & Lactarius deterrimus Gröger & 0,0044 & 0,0012 \\
\hline 2 & Suillus granulatus (L.) Roussel & 0,0007 & 0,0008 \\
\hline 3 & Lactariuss crobiculatus (Britzelm.) Killerm. & 0,0015 & 0,0103 \\
\hline 4 & Boletus edulis Bull. & 0,0011 & 0,0296 \\
\hline 5 & Cortinarius odorifer Britzelm. & 0,0100 & 0,0059 \\
\hline $5-7$ & Sarcodon imbricatus (L.) P. Karst & 0,0020 & 0,0049 \\
\hline 6 & Cantharellus tubaeformis Fr. & 0,0029 & 0,0014 \\
\hline 6 & Lactarius trivialis (Fr.) Fr. & 0,0029 & 0,0021 \\
\hline 7 & Cortinarius armeniacus Fr. & 0,0059 & 0,0149 \\
\hline 8 & Cortinarius sp. & 0,0119 & 0,2105 \\
\hline $8-10$ & Hypholoma capnoides (Fr.) P. Kumm ${ }^{a}$ & 0,0149 & 0,0429 \\
\hline $8-10$ & Tricholoma equestre (L.) P. Kumm. & 0,0224 & 0,0714 \\
\hline 10 & Collybia peronata (Bolton) P. Kumm ${ }^{a}$ & 0,0746 & 0,0857 \\
\hline
\end{tabular}

Примітка: ${ }^{a}$ - сапротрофи.

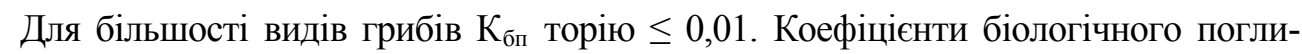
нання урану майже на порядок вищі, але не перевищують 0,2. Вміст урану у плодових тілах варіює у ширшому діапазоні, ніж вміст нікелю. Коефіцієнт варіації величини $\mathrm{K}_{\text {бп }}$

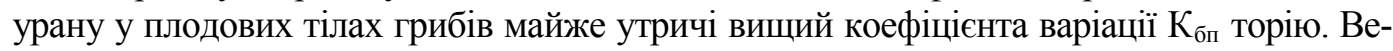
личини $\mathrm{K}_{\text {бп }}$ урану та торію грибами, одержані у цьому дослідженні, збігаються із даними інших авторів. Величини коефіцієнтів переходу торію та урану у плодові тіла грибів, що зростали у лісових екосистемах Іспанії, складали 0,03-0,62 та 0,04-0,49 відповідно [2]. Види роду Cortinarius поглинають уран на один - два порядки інтенсивніше, ніж інші досліджувані види. Щодо вмісту торію у грибах, сапротрофні види, такі як Collybia

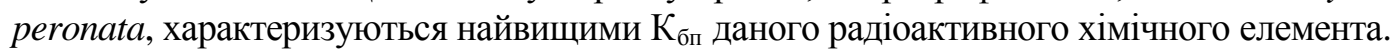
Види родини кортинарієвих (Cortinariaceae), зокрема Gymnopilus hybridus (Fr.) Maire, відомі як ті, для яких характерні підвищені рівні обох досліджуваних природних радіоактивних елементів [5]. Згідно з даними іспанських учених Baeza \& Guillén [2], найвищі коефіцієнти біологічного поглинання торію та урану характерні для іншого представника родини кортинарієвих - ектомікоризного виду Hebeloma cylindrosporum Romagn., який часто зустрічається на піщаних лісових грунтах із низьким вмістом органічної речовини. Через виняткову здатність поглинати радіоактивні елементи даний вид використовується як біоіндикатор радіоактивного забруднення грунту. Хоча відомо, що обмінні процеси у грибах найінтенсивніше відбуваються у їх плодових тілах [1], наші дані показують, що концентрація торію та урану в міцелії грибів більше ніж на два порядки перевищує концентрацію у плодових тілах. Відмінності концентрації елементів у плодових тілах і міцелії грибів свідчать про те, що обидва 
елементи поглинаються грибним міцелієм, але до плодових тіл грибів надходить лише їх незначна частка.

За величинами $\mathrm{K}_{\text {бп }}$ торію досліджувані гриби та фракції лісового грунту можна розмістити у такий спадний ряд: ризосфера $>$ едафосфера $>$ міцелій $>$ ризоплана $>$

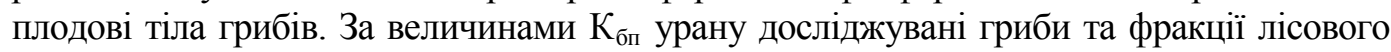
грунту можна розмістити у такий спадний ряд: ризосфера $>$ едафосфера $>$ ризоплана $>$ міцелій > плодові тіла грибів. Однак статистично відмінною є лише концентрація торію у фракціях ризоплана та едафосфера.

Вміст урану та торію у грибах залежить від концентрації цих ізотопів у грунті (едафосфері). Статистично достовірною така залежність виявлена між вмістом урану у плодових тілах і концентрацією його у грунті $(r=0,91 * * *)$, а також між вмістом торію у міцелії грибів і концентрацією його у грунті $\left(r=0,78^{* *}\right)$ (рис. 1,2$)$.
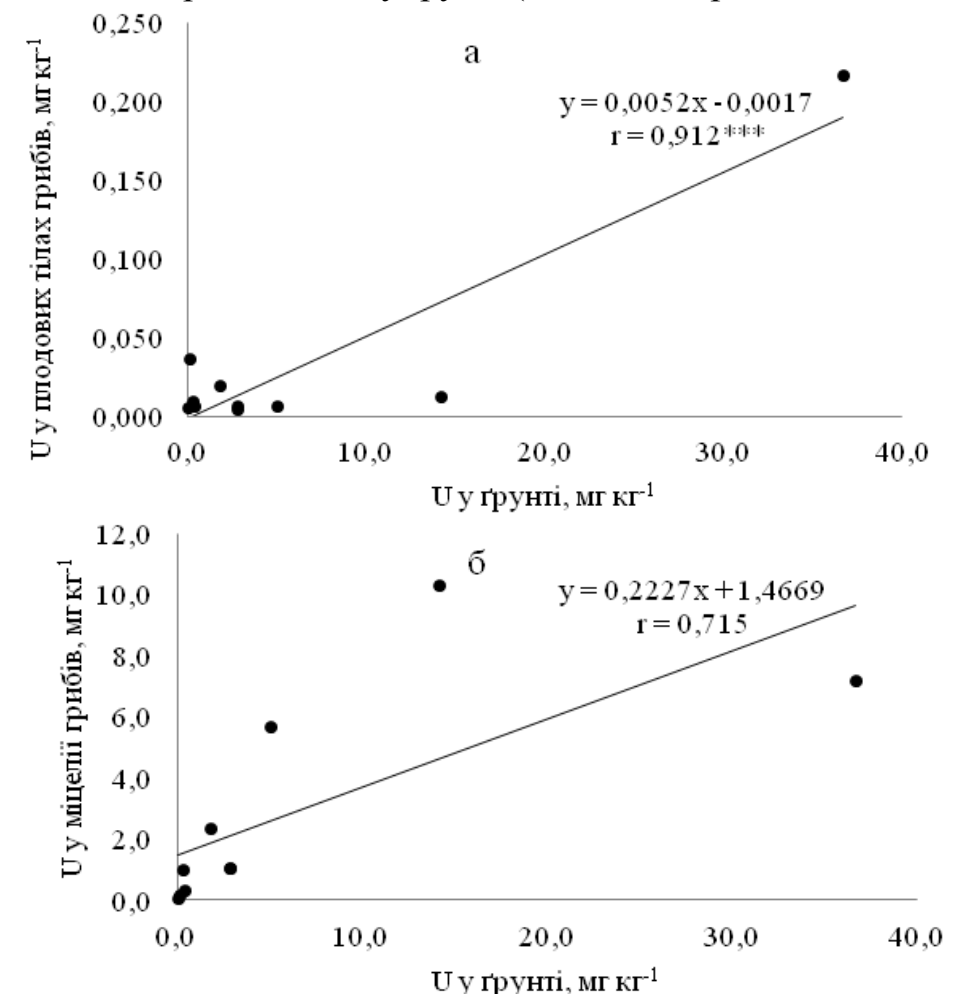

Рис. 1. Співвідношення між концентрацією урану у грибах та грунті, у якому вони зростали: $a-$ концентрація урану у плодових тілах грибів і грунті;
$\sigma$ - конщентрація урану в міцелії грибів і грунті; *** $-p<0,001$

Між вмістом урану у міцелії грибів і концентрацією цього природного ізотопу у грунті, а також між вмістом торію у плодових тілах грибів і концентрацією його у грунті зв'язок недостовірний (див. рис. 1, 2). Імовірна причина цього - варіювання вмісту досліджуваних природних ізотопів у широкому діапазоні як у грунті, так і у грибах. Концентрація урану у грунтових зразках змінювалась від 0,07 до 36,7 мг/кг сухої ваги.

Біомаса міцелію у верхніх (0-5 cм) шарах досліджуваних лісових грунтів варіювала від 30 до 60 мг сухої ваги в одному грамі грунту. При щільності грунту у районі досліджень 0,4 г/см [12], питомий вміст міцелію у цьому шарі становитиме 3-6 \% за об'ємом. При такому вмісті міцелію у грунті у ньому може бути зосереджена лише незначна частина загальної кількості торію та урану едафосфери. При концентрації торію 
та урану у міцелії 0,74 та 3,11 мг/кг сухої ваги в ньому може бути зосереджено 2,0-5,0 та 1,4-2,7 \% торію та урану від їх загального вмісту у грунті відповідно.
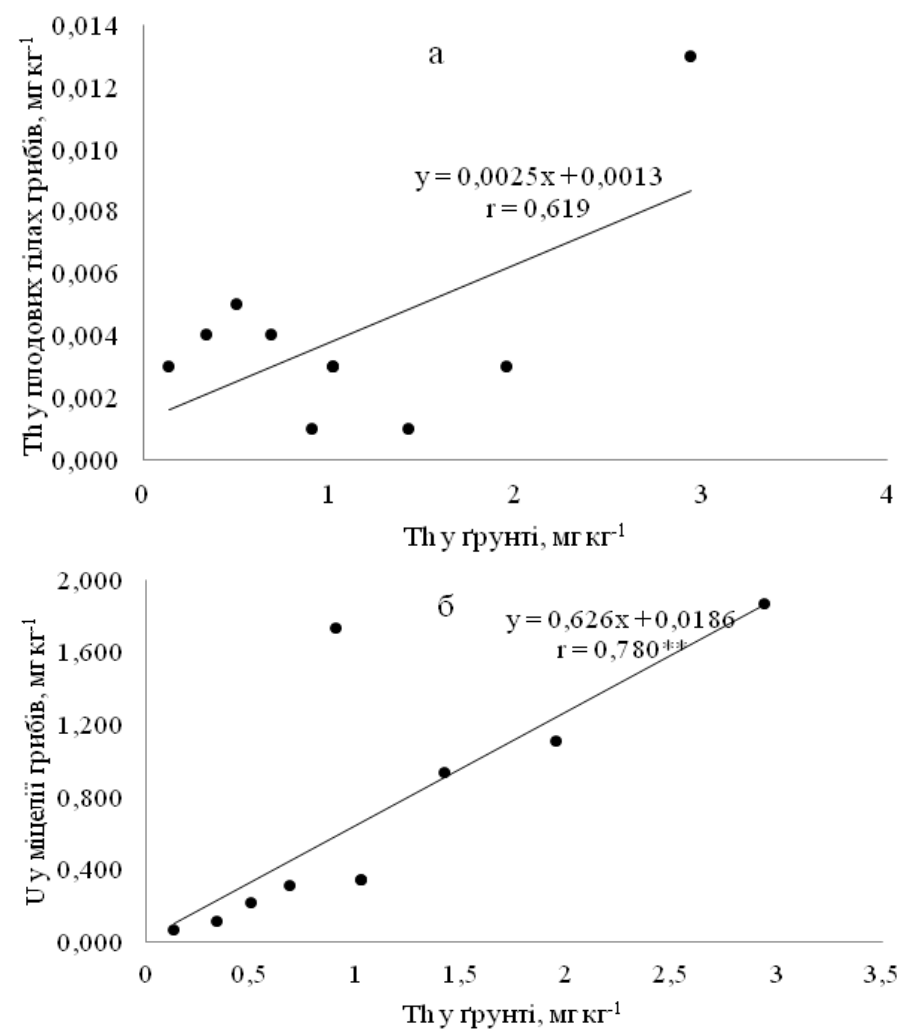

Рис. 2. Співвідношення між концентрацісю торію у грибах і грунті, у якому вони зростали: $a-$ концентрація торію у плодових тілах грибів і грунті;

$\sigma$ - концентрація торію в міцелії грибів і грунті; ** $p<0,01$

Наведені оцінки досить добре збігаються з даними інших досліджень. Berthelsen et al. [3] показано, що в міцелії грибів, які зростають у грунтах лісових екосистем Норвегії, може бути зосереджено близько $2 \%$ свинцю $(P b)$ від загального його вмісту у грунті. Разом із цим відомо, що міцелій грибів може вміщувати у собі 15,5-31,7 \% загального вмісту кадмію $(C d)$ верхнього $(0-5$ см) шару лісового грунту (неопубліковані дані автора). Слід зауважити, що прямий метод оцінки біомаси міцелію, використаний нами, імовірно, не забезпечував повного вилучення міцелію грунту. Особливо це стосується верхніх, збагачених органікою грунтових шарів, де гіфи міцелію тісно переплетені з напіврозкладеними органічними рештками. Тому наведені дані щодо вмісту торію та урану у міцелії грибів швидше недооцінені, ніж переоцінені.

\section{Висновки}

Концентрація торію варіює в межах від 0,0041 мг/кг сухої ваги у плодових тілах грибів до 1,45 мг/кг сухої ваги у фракції ризосфера. Концентрація урану змінюється від 0,026 мг/кг сухої ваги у плодових тілах грибів до 9,36 мг/кг сухої ваги у фракції ризосфера. Обидва природні ізотопи не накопичуються ані міцелієм грибів, ані їх плодовими тілами: коефіцієнти біологічного поглинання урану та торію плодовими тілами у середньому становлять 0,035 та 0,006 відповідно. Вміст досліджуваних ізотопів торію та урану у плодових тілах грибів у 270 разів нижчий, ніж у загальній масі грунту - еда- 
фосфері. Вміст торію та урану як у міцелії грибів, так і плодових тілах залежить від концентрації цих елементів у грунті: зі збільшенням концентрації цих елементів у грунті їх вміст у грибах також підвищується. У міцелії грибів верхнього (0-5 см) шару лісового грунту може бути зосереджено 2,0-5,0 та 1,4-2,7 \% торію та урану від їх загального вмісту у грунті відповідно.

Автор висловлює подяку проф. К. Йохансону, д-ру І. Ніколова та А. Тейлор за допомогу у проведенні експериментів, а також співробітникам лабораторії Analytica, ALSScandinaviaAB, Luleå. Фінансову підтримку проекту одержано від SKB (Агентство з питань ядерної безпеки Швеції).

\section{Бібліографічні посилання}

1. Цветнова О. Б. Накопление радионуклидов и тяжелых металлов грибным комплексом лесных экосистем / О. Б. Цветнова, Н. Е. Шатрова, А. И. Щеглов // Науч. тр. Ин-та ядерных исследований. - К., 2001. - № 3 (5). - С. 171-176.

2. Baeza A. Influence of the soil bioavailability of radionuclides on the transfer of uranium and thorium to mushrooms / A. Baeza, J. Guillén // Appl. Radiat. Isotop. - 2006. - Vol. 64 (9). - P. 1020-1026.

3. Berthelsen B. O. Ectomycorrhizal heavy metal accumulation as a contributing factor to heavy metal levels in organic surface soils / B. O. Berthelsen, R. A. Olsen, E. Steinnes // Sci. Total Environ. 1995. - Vol. 170 (1-2). - P. 141-149.

4. Burgess T. I. The ability of 16 ectomycorrhizal fungi to increase growth and phosphorus uptake of Eucalyptus globulus Labill. and E. diversicolor F. Muell / T. I. Burgess, N. Maljczuk, T. S. Grove // Plant Soil. - 1993. - Vol. 153. - P. 155-164.

5. Campos J. A. Substrate role in the accumulation of heavy metals in sporocarps of wild fungi / J. A. Campos, N. A. Tejera, C. J. Sánchez // Biometals. - 2009. - Vol. 22 (5). - P. 835-841.

6. Gorban G. R. A conceptual model for nutrient availability in the mineral soil-root system / G. R. Gorban, S. Clegg // Can. J. Soil Sci. - 1996. - Vol. 76. - P. 125-131.

7. Leake J. R. Mycorrhizal fungi in terrestrial habitats / J. R. Leake, D. J. Read // D. T. Wicklow, B. Söderström, Eds., The Mycota IV: Environmental and Microbial Relationship. - Berlin: SpringerVerlag, 1997. - P. 281-301.

8. Levels of inorganic constituents in raw nuts and seeds on the Swedish market / I. Rodushkin, E. Engström, D. Sörlin, D. Baxter // Sci. Total Environ. - 2008. - Vol. 392. - P. 290-304.

9. Mushrooms from two metal-contaminated areas in Norway: Occurrence of metals and metallothionein-like proteins / C. Collin-Hansen, K. E. Yttri, R. A. Andersen et al. // Geochemistry: Exploration, Environment, Analysis. - 2002. - Vol. 2 (2). - P. 121-130.

10. Recovery of uranium (VI) from solution using precultured Penicillium biomass / M. Galun, P. Keller, D. Malki et al. // Water Air Soil Pollut. - 1983. - Vol. 20. - P. 221-232.

11. Smith S. E. Mycorrhizal symbiosis / S. E. Smith, D. J. Read. - London : Academic Press, 1997. -605 p.

12. Soils and site types in the Forsmark area / L. Lundin, E. Lode, J. Stendahl et al. // SKB-rapport. P-04243. - Stockholm, Sweden : Swedish Nuclear Fuel and Waste Management Co., 2004. - 102 p.

13. Thomet U. The uptake of cadmium and zinc by mycelia and their accumulation in mycelia and fruiting bodies of edible mushrooms / U. Thomet, E. Vogel, U. Krähenbühl // Eur. Food Res. Technol. - 1999. - Vol. 209 (5). - P. 317-324.

14. Uranium, thorium and rare earth elements in macrofungi: What are the genuine concentrations? / J. Borovička, J. Kubrová, J. Rohovec et al. // Biometals. - 2011.- Vol. 24 (5). - P. 837-845.

15. Vetter J. Zinc content of sporocarps of basidiomycetous fungi / J. Vetter, I. Siller, Z. Horváth // Mycologia. - 1997. - Vol. 89. - P. 481-483.

16. Vinichuk M. M. Accumulation of ${ }^{137}$ Cs by fungal mycelium in forest ecosystems of Ukraine / M. M. Vinichuk, K. J. Johanson // J. Environ. Radioact. - 2003. - Vol. 64 (1). - P. 27-43.

Надійшла до редколегї 14.07.2012 